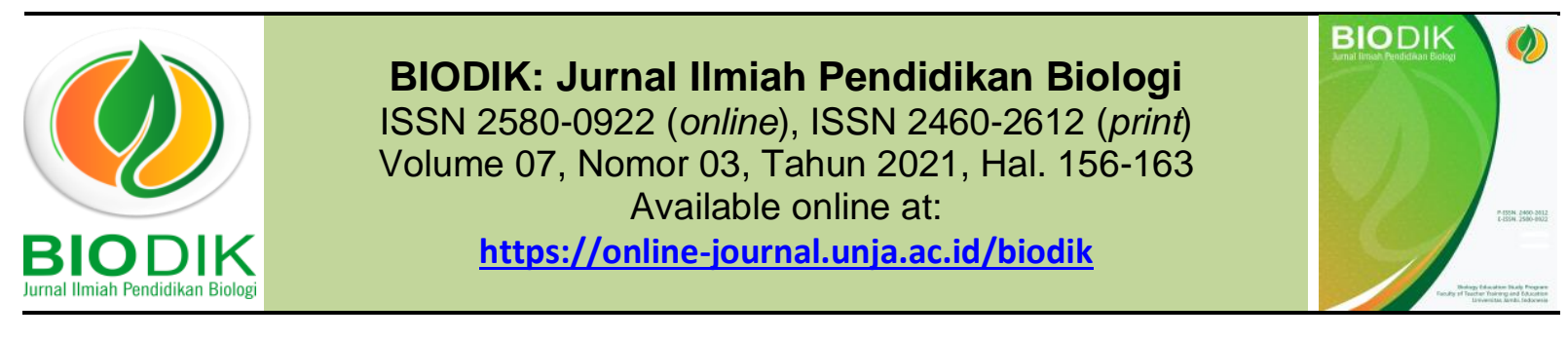

Research Article

OPEN ACCESS

\title{
Profil Kemampuan Penalaran IImiah Siswa SMP Berdasarkan Gaya Belajar
}

\section{(Profile of Scientific Reasoning Ability of Junior High School Students Based on Learning Style)}

\author{
Siti Nurjanah Firdaus*, Suhendar, Billyardi Ramdhan
}

Universitas Muhammadiyah Sukabumi

JI R.Syamsudin SH No.50 Kec. Cikole Kota Sukabumi

*Corresponding Author: sitinurjanahfirdaus@gmail.com

\begin{tabular}{|c|c|}
\hline Informasi Artikel & ABSTRACT \\
\hline $\begin{array}{l}\text { Submit: } 17-06-2021 \\
\text { Diterima: } 30-08-2021 \\
\text { Dipublikasikan: } 29-09-2021\end{array}$ & $\begin{array}{l}\text { This study aims to describe the scientific reasoning abilities of junior high school } \\
\text { students in science learning based on learning styles at SMPN } 15 \text { Sukabumi } \\
\text { City. The sample in this study was } 35 \text { students of class VII SMPN } 15 \text { Sukabumi } \\
\text { in the academic year 2020/2021. This research uses qualitative methods through } \\
\text { a descriptive approach. The research instruments used were questionnaires and } \\
\text { scientific reasoning test instruments Lawson Classroom Test of Scientific } \\
\text { Reasoning (LCTSR) which consisted of } 12 \text { reasoned multiple choice questions } \\
\text { containing } 6 \text { indicators of scientific reasoning, namely: proportional reasoning, } \\
\text { probabilistic, correlational, conservation, variable control, and hypothetical. } \\
\text { deductive. The results showed that the learning style most often used by junior } \\
\text { high school students was the visual learning style. This is evidenced by the } \\
\text { results of questionnaires that have been distributed, as many as } 17 \text { students or } \\
48.58 \% \text { of the } 35 \text { students analyzed tended to use visual learning styles } \\
\text { compared to auditory and kinesthetic learning styles. Students with this visual } \\
\text { learning style have better scientific reasoning abilities. In addition, overall junior } \\
\text { high school students do not yet have the ability to compare two variables of a } \\
\text { phenomenon based on a constant ratio, which means junior high school students } \\
\text { have scientific reasoning skills on low hypothesis-deductive indicators. } \\
\text { Key words: Scientific ReasoningAbility, Learning Style }\end{array}$ \\
\hline Penerbit & ABSTRAK \\
\hline \multirow[t]{2}{*}{$\begin{array}{l}\text { Program Studi Pendidikan Biologi } \\
\text { FKIP Universitas Jambi, } \\
\text { Jambi- Indonesia }\end{array}$} & $\begin{array}{l}\text { Penelitian ini bertujuan untuk mendeskripsikan kemampuan penalaran ilmiah } \\
\text { siswa SMP pada pembelajaran IPA berdasarkan gaya belajar di SMPN } 15 \text { Kota } \\
\text { Sukabumi. Sampel pada penelitian ini yaitu } 35 \text { siswa kelas VII SMPN } 15 \text { kota } \\
\text { sukabumi tahun ajaran } 2020 / 2021 \text {. Penelitian ini menggunakan metode kualitatif } \\
\text { melalui pendekatan deskriptif. Instrumen penelitian yang digunakan yaitu angket } \\
\text { dan instrumen tes penalaran ilmiah Lawson Classroom Test of Scientific } \\
\text { Reasoning (LCTSR) yang terdiri } 12 \text { soal pilihan ganda beralasan yang memuat } \\
6 \text { indikator penalaran ilmiah yaitu: penalaran proporsional, probabilistik, } \\
\text { korelasional, konservasi, pengontrolan variabel, dan hipotetic-deduktif. Hasil } \\
\text { penelitian menunjukkan bahwa gaya belajar yang paling banyak digunakan oleh } \\
\text { siswa smp adalah gaya belajar visual. Hal ini dibuktikan dari hasil angket yang } \\
\text { telah disebar, sebanyak } 17 \text { siswa atau } 48,58 \% \text { dari } 35 \text { siswa yang dianalisis } \\
\text { cenderung menggunakan gaya belajar visual dibandingkan gaya belajar } \\
\text { auditorial maupun kinestetik. Siswa dengan gaya belajar visual ini memiliki } \\
\text { kemampuan penalaran ilmiah yang lebih baik. Selain itu, secara keseluruhan } \\
\text { siswa smp belum memiliki kemampuan untuk membandingkan dua varibel suatu } \\
\text { fenomena berdasarkan rasio konstan yang artinya siswa smp memiliki } \\
\text { kemampuan penalaran ilmiah pada indikator hipotesis-deduktif yang rendah. }\end{array}$ \\
\hline & Kata kunci: Kemampuan Penalaran IImiah, Gaya Belajar \\
\hline
\end{tabular}


This BIODIK : Jurnal IImiah Pendidikan Biologi is licensed under a CC BY-NC-SA (Creative Commons Attribution-ShareAlike 4.0 International License)

\section{PENDAHULUAN}

Belajar merupakan proses mendapatkan suatu ilmu, dari apa yang tidak kita ketahui menjadi tahu. Suatu ilmu tidak akan didapat dengan sendirinya melainkan harus melalui suatu proses pembelajaran. Peserta didik akan merasa nyaman jika pembelajaran dilakukan secara efektif, sehingga kemampuan penalaran ilmiah peserta didik pun akan meningkat. Penalaran (reasoning) juga dapat dikatakan sebagai suatu cara berfikir yang dimaksudkan untuk menarik kesimpulan dari sebuah premis. Salah satu peranan penalaran yaitu dalam proses pemecahan masalah (Bachtiar, 2013).

Penalaran merupakan suatu aktivitas berpikir secara sadar dan sistematis yang dimaksudkan untuk menarik kesimpulan yang sahih dan benar. Penalaran ini bersifat logis dan analisis sebagai hasil sintesis antara penalaran induktif yang empiris dan penalaran induktif yang rasional (Sutarno \& Bengkulu, 2017). Temuan penelitian pada jurnal yang berjudul "Evaluation of the Scientific Reasoning Skills of 7th Grade Students in Science Course" menunjukkan bahwa kemampuan penalaran ilmiah peserta didik smp pada ilmu sains sangat rendah. Padahal, penalaran ilmiah adalah komponen penting di bawah alur kognitif keterampilan abad ke-21 dan sangat ditekankan dalam standar pendidikan sains yang baru. Keterampilan penalaran ilmiah saat ini dipandang sebagai alat yang diperlukan untuk pengembangan konseptual dan epistemologis siswa dalam memahami ilmu pengetahuan (Bo, 2019; Zhou et al., 2016). Dalam proses peningkatan kemampuan, siswa harus dibekalkan sebuah instruksi yang dapat mempengaruhi siswa untuk dapat berkembang hingga level paling tinggi. Oleh sebab itu, dalam proses pembelajaran harus dibekalkan kemampuan penalaran ilmiah sebagai proses inkuiri kritis (Yuliati et al., 2016).

Gaya belajar memiliki peranan penting dalam suatu proses pembelajaran. Mengenali gaya belajar seseorang akan dapat menentukan cara pembelajaran yang efektif. Gaya belajar mengarah pada cara belajar yang lebih disukai siswa sehingga gaya belajar akan berpengaruh terhadap prestasi akademik siswa. Dengan mengetahui gaya belajar siswa, guru dapat membantu siswa belajar sesuai dengan gaya belajar yang dimiliki siswa sehingga prestasi belajar siswa akan tumbuh dengan baik melalui pembelajaran yang sesuai dengan gaya belajarnya. Belajar biologi atau sains secara bermakna baru akan dialami siswa apabila siswa terlibat aktif secara intelektual, manual, dan social ((Ramdhan et al., 2012).

Gaya belajar seseorang merupakan kombinasi dari bagaimana ia menyerap, mengatur dan mengolah informasi. Pada umumnya gaya belajar seseorang ini dianggap berasal dari variabel kepribadian, pengetahuan, psikologis, latar belakang sosio cultural, dan pengalaman pendidikan (Mufidah, 2017). Kemampuan siswa untuk memahami dan menyerap pelajaran sudah pasti berbeda tingkatnya. Ada yang cepat, sedang dan ada pula yang sangat lambat. Karenanya, mereka seringkali harus menempuh cara berbeda untuk bisa memahami sebuah informasi atau pelajaran yang sama. Sebagian siswa lebih suka jika guru mereka mengajar dengan cara menuliskan segalanya di papan tulis, dengan begitu mereka bisa membaca untuk kemudian mencoba memahaminya. Akan tetapi, sebagian siswa lain lebih suka jika guru mereka mengajar dengan cara menyampaikannya secara lisan dan mereka mendengarkan untuk bisa memahaminya. Sementara itu, ada siswa yang lebih suka membentuk 
kelompok kecil untuk mendiskusikan pertanyaan yang menyangkut pelajaran tersebut. Cara lain yang juga kerap disukai banyak siswa adalah model belajar yang menempatkan guru tak ubahnya sebagai seorang penceramah. Guru diharapkan bercerita panjang lebar tentang beragam teori dengan segudang ilustrasinya, sementara para siswa mendengarkan sambil menggambarkan isi ceramah itu dalam bentuk yang hanya mereka pahami sendiri.

Terdapat beberapa tipe gaya belajar yaitu gaya belajar visual, auditorial, dan kinestetik. Gaya belajar visual merupakan gaya belajar dimana siswa lebih banyak menggunakan indra penglihatan dalam proses pembelajaran, sehingga siswa cenderung belajar dari apa yang mereka lihat. Berbeda dengan gaya belajar visual, gaya belajar tipe auditorial merupakan gaya belajar dimana siswa cenderung lebih menggunakan indra pendengaran dalam proses pembelajaran. Siswa dengan tipe gaya belajar ini cenderung lebih suka mendengarkan hal-hal yang disampaikan oleh orang lain dibandingkan harus membaca sendiri. Tipe gaya belajar selanjutnya adalah gaya belajar kinestetik. Seseorang dengan tipe gaya belajar ini memiliki kecendrungan belajar melalui gerakan, artinya seseorang dengan tipe gaya belajar ini akan belajar sangat baik apabila terlibat secara fisik dalam kegiatan pembelajaran (Chania et al., 2016; Daik et al., 2020).

Dalam proses pembelajaran di kelas, hendaknya guru tidak hanya memperhatikan strategi dalam mengajarnya saja tapi juga memperhatikan perbedaan karakteristik masing-masing siswa karena pada dasarnya setiap siswa memiliki cara atau gaya belajar yang berbeda-beda. Dalam hubungannya dengan pembelajaran, pengajar seharusnya melakukan obserbasi, eksplorasi dan penelitian sebelum melakukan kegiatan pembelajaran, sehingga dapat menentukkan pendekatan, strategi, model, dan metode pembelajaran yang tepat untuk mengakomodasi keseluruhan gaya belajar siswa. Upaya yang dapat dilakukan pengajar adalah memperhatikan gaya belajar siswa dengan cara pengelompokan berdasarkan gaya belajar. Sebaiknya guru dapat melayani semua siswa dengan ketiga gaya belajar tersebut. Guru membantu setiap siswa untuk melibatkan seluruh gaya belajar yang dimilikinya, karena dengan melibatkan seluruh gaya belajar tersebut akan dapat membantu siswa untuk memahami materi pelajaran yang diterimanya. Pada pembelajaran ini, guru akan mengalami kerepotan di awal pembelajaran pada saat menyiapkan bahan ajar karena guru harus bisa melayani keperluan siswa sesuai gaya belajarnya. Hal ini berarti guru harus menyampaikan bahan ajar dengan cara yang bervariasi. Jika bahan ajar disampaikan sesuai dengan jenis gaya belajar maka siswa yang bersangkutan dapat mencapai hasil belajar yang maksimal.

Setiap individu memiliki kemampuan untuk menyerap dan memahami materi pembelajaran yang berbeda-beda. Begitupun dengan gaya belajar, tidak semua siswa memiliki gaya belajar yang sama meskipun berada dalam satu lingkungan sekolah. Dengan gaya belajar yang berbeda, maka kemampuan penalaran setiap siswa akan berbeda pula. Hal ini dibuktikan oleh hasil penelitian Haryono (Haryono, 2018) yang menyatakan bahwa siswa yang memiliki gaya belajar visual memiliki kemampuan penalaran induktif matematika yang lebih baik dibandingkan siswa dengan gaya belajar auditorial ataupun kinestetik. Berdasarkan hal tersebut maka dilakukan penelitian yang bertujuan untuk mendeskripsikan kemampuan penalaran ilmiah siswa SMP pada pembelajaran IPA berdasarkan gaya belajar.

\section{METODE PENELITIAN}

Penelitian ini menggunakan metode kualitatif melalui pendekatan deskriptif. Data kualitatif yang diperoleh dideskripsikan untuk mengetahui dan mengukur kemampuan penalaran ilmiah siswa smp berdasarkan gaya belajarnya. Sampel pada penelitian ini yaitu 35 siswa kelas VII SMPN 15 kota 
sukabumi tahun ajaran 2020/2021. Pengambilan sampel penelitian ini menggunakan teknik purposive sampling yang didasarkan atas adanya tujuan tertentu. Prosedur pada penelitian ini terdiri dari tiga tahap yaitu tahap persiapan, tahap pelaksanaan, dan tahap penarikan kesimpulan. Instrumen yang digunakan dalam penelitian ini yaitu instrumen tes untuk mengukur kemampuan penalaran ilmiah siswa dan angket untuk mengetahui gaya belajar dari setiap siswa.

Instrumen tes penalaran ilmiah yang digunakan yaitu instrumen Lawson Classroom Test of Scientific Reasoning (LCTSR) yang terdiri 12 soal pilihan ganda beralasan yang memuat 6 indikator penalaran ilmiah yaitu: penalaran proporsional, probabilistik, korelasional, konservasi, pengontrolan variabel, dan hipotetic-deduktif. Pada tahap skoring setiap butir soal diberi skor 2 apabila soal konten dan soal alasan benar, apabila soal konten benar dan soal alasan salah diberi skor 1, dan apabila soal konten maupun soal alasan salah maka diberi skor 0 . Guna penarikan kesimpulan, maka data yang diperoleh dikategorikan berdasarkan kemampuan penalaran ilmiah dan gaya belajar seorang siswa. Adapun kategori kemampuan penalaran ilmiah disajikan pada tabel 1.

Tabel 1. Kategori Jawaban Soal Penalaran IImiah

\begin{tabular}{cccc}
\hline Soal Konten & Soal Alasan & Nilai & Kategori \\
\hline Benar & Benar & 2 & Baik \\
Benar & Salah & 1 & Cukup \\
Salah & Salah & 0 & Kurang \\
\hline
\end{tabular}

\section{HASIL PENELITIAN DAN PEMBAHASAN}

Berdasarkan hasil penelitian melalui angket gaya belajar, maka diperoleh presentase kategori gaya belajar siswa SMPN 15 kota sukabumi. Gaya belajar siswa SMP meliputi gaya belajar visual, gaya belajar auditorial dan gaya belajar kinestetik. Gaya belajar siswa SMP tersebut disajikan pada grafik yang dapat dilihat pada gambar 1 .

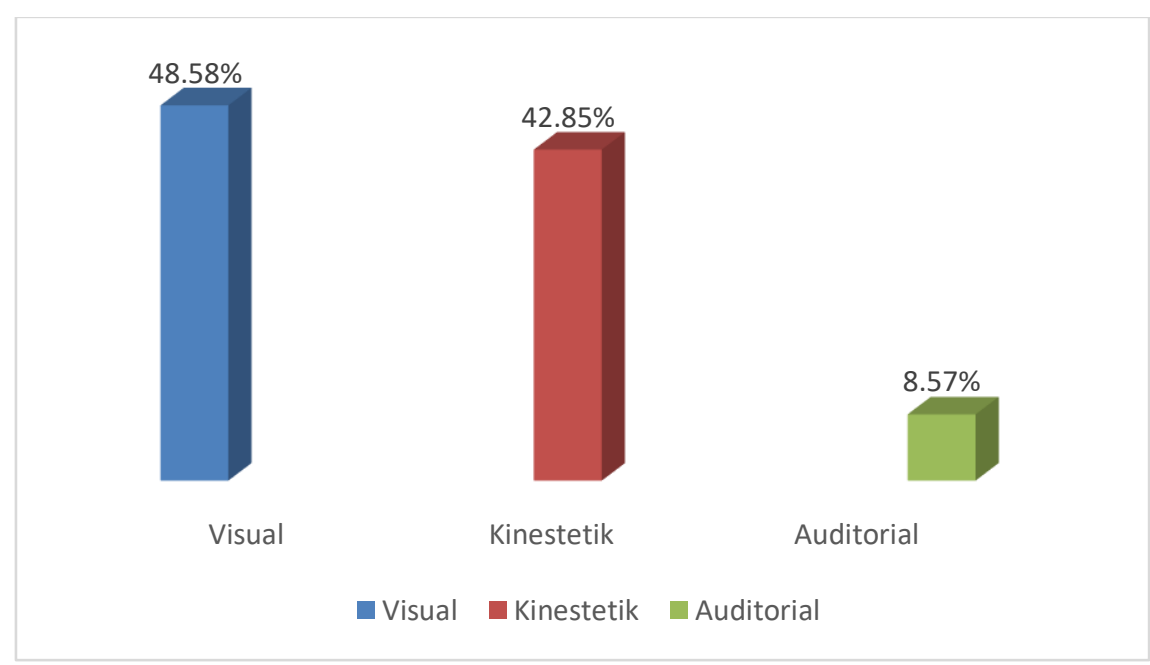

Gambar 1. Grafik Presentase Gaya Belajar Siswa SMP 
Berdasarkan grafik di atas, dapat diketahui bahwa gaya belajar yang paling banyak digunakan oleh siswa smp adalah gaya belajar visual. Hal ini dibuktikan dari hasil angket yang telah disebar, sebanyak 17 siswa atau 48,58\% dari 35 siswa yang dianalisis cenderung menggunakan gaya belajar visual. Hal ini membuktikan bahwa siswa SMP cenderung menggunakan penglihatan dalam melaksanakan kegiatan pembelajaran. Selanjutnya, gaya belajar kedua yang banyak digunakan oleh siswa smp adalah gaya belajar kinestetik yaitu sebanyak 15 siswa atau 42,85\% dari 35 siswa yang dianalisis menggunakan gaya belajar kinestetik dalam proses pembelajaran. Hal ini menunjukkan bahwa siswa smp cenderung memiliki rasa ingin menyentuh langsung benda yang menjadi materi pembelajaran serta mengungkapkan minat dan ketertarikan terhadap sesuatu secara fisik.

Selanjutnya, kemampuan penalaran ilmiah siswa SMP diukur menggunakan instrumen tes Lawson Classroom Test of Scientific Reasoning (LCTSR) yang terdiri dari 12 soal pilihan ganda beralasan yang memuat 6 indikator penalaran ilmiah yaitu: penalaran proporsional, probabilistik, korelasional, konservasi, pengontrolan variabel, dan hipotetic-deduktif. Kemampuan penalaran ilmiah untuk salah satu contoh siswa yang memiliki gaya belajar visual pada setiap butir soal disajikan pada tabel 2 .

Tabel 2. Kemampuan Penalaran IImiah Siswa Gaya Belajar Visual

\begin{tabular}{lll}
\hline \multirow{2}{*}{ Indikator Penalaran IImiah } & \multicolumn{2}{c}{ Butir Soal } \\
\cline { 2 - 3 } & Kurang & kurang \\
\hline Penalaran proporsional & Baik & Baik \\
\hline Pengontrol variabel & Baik & Cukup \\
\hline Penalaran korelasi & Baik & Baik \\
\hline Penalaran probalistic & Kurang & Kurang \\
\hline Penalaran hipotesis-deduktif & Baik & Baik \\
\hline Penalaran konservasi & &
\end{tabular}

Berdasarkan data pada tabel 2 dapat diketahui bahwa kemampuan penalaran ilmiah siswa dengan gaya belajar visual untuk setiap indikator soal bernilai baik, kecuali pada indikator penalaran proporsional dan penalaran hipotesis-deduktif yang memiliki rentang nilai kurang. Hal ini menunjukkan bahwa siswa belum memiliki kemampuan untuk membandingkan dua varibel suatu fenomena berdasarkan rasio konstan serta siswa belum memiliki kemampuan untuk membuat hipotesis dari sebuah teori dalam memecahkan suatu masalah. Sedangkan, untuk indikator penalaran pengontrolan variabel siswa dengan gaya belajar visual memiliki rentang nilai baik, artinya siswa dengan gaya belajar ini memiliki kemampuan untuk mengontrol variabel yang diperlukan dalam proses penyelidikan.

Pada indikator penalaran korelasi dan penalaran probabilistic, siswa dengan gaya belajar visual memiliki rentang nilai baik. Penalaran korelasi merupakan penalaran yang digunakan untuk mengidentifikasi hubungan timbal balik antar variabel, sedangkan penalaran probabilistic merupakan penalaran dalam menggunakan informasi untuk membuat suatu kesimpulan yang mungkin terjadi berdasarkan perhitungan peluang. Pada indikator penalaran konservasi, siswa dengan gaya belajar visual juga memiliki rentang nilai baik, artinya siswa dengan gaya belajar ini memiliki pemahaman bahwa sifat-sifat tertentu pada suatu benda tidak berubah. Hasil berbeda ditunjukkan oleh salah satu siswa dengan gaya belajar kinestetik. Kemampuan penalaran ilmiah untuk salah satu contoh siswa yang memiliki gaya belajar kinestetik pada setiap butir soal disajikan pada tabel 3 . 
Tabel 3. Kemampuan Penalaran IImiah Siswa Gaya Belajar Kinestetik

\begin{tabular}{lll}
\hline \multirow{2}{*}{ Indikator Penalaran IImiah } & \multicolumn{2}{c}{ Butir Soal } \\
\cline { 2 - 3 } & Cukup & Cukup \\
\hline Penalaran proporsional & Cukup & Baik \\
\hline Pengontrol variabel & Cukup & Baik \\
\hline Penalaran korelasi & Kurang & Kurang \\
\hline Penalaran probalistic & Kurang & Baik \\
\hline Penalaran hipotesis-deduktif & Baik & Baik \\
\hline Penalaran konservasi &
\end{tabular}

Berdasarkan tabel 3 dapat diketahui bahwa siswa dengan gaya belajar kinestetik untuk setiap indikator soal bernilai baik dan cukup, kecuali pada indikator penalaran probabilistik dan penalaran hipotesis-deduktif memiliki rentang nilai kurang. Berbeda dengan siswa yang memiliki gaya belajar visual, siswa dengan gaya belajar kinestetik memiliki kemampuan penalaran proporsional yang cukup. Artinya, siswa dengan gaya belajar kinestetik ini memiliki cukup kemampuan untuk membandingkan dua varibel suatu fenomena berdasarkan rasio konstan dengan baik. Pada indikator penalaran ilmiah pengontrolan variabel dan penalaran korelasi memiliki rentang nilai cukup baik, artinya siswa dengan gaya belajar ini sudah memiliki kemampuan untuk mengontrol variabel yang diperlukan dalam proses penyelidikan serta siswa memiliki kemampuan untuk mengidentifikasi hubungan timbal balik antar variabel.

Sama halnya dengan siswa yang memiliki gaya belajar visual, tabel di atas juga menunjukkan bahwa siswa dengan gaya belajar kinestetik untuk indikator penalaran hipotesis-deduktif memiliki rentang nilai kurang, artinya siswa dengan gaya belajar auditorial ini belum memiliki kemampuan untuk membuat hipotesis dari sebuah teori dalam memecahkan suatu masalah. Pada indikator penalaran probabilistic memiliki rentang nilai kurang yang artinya siswa dengan gaya belajar kinestetik memiliki kemampuan menggunakan informasi untuk membuat suatu kesimpulan yang mungkin terjadi berdasarkan perhitungan peluang yang rendah. Sedangkan, untuk indikator penalaran konservasi memiliki rentang nilai baik yang berarti siswa dengan gaya belajar kinestetik memiliki pemahaman bahwa sifat-sifat tertentu pada suatu benda tidak berubah.

Hasil berbeda juga ditunjukkan oleh salah satu siswa dengan gaya belajar auditorial. Kemampuan penalaran ilmiah untuk salah satu contoh siswa yang memiliki gaya belajar auditorial pada setiap butir soal disajikan pada tabel 4 .

Tabel 4. Kemampuan Penalaran Ilmiah Siswa Gaya Belajar Auditorial

\begin{tabular}{llc}
\hline \multirow{2}{*}{ Indikator Penalaran IImiah } & \multicolumn{2}{c}{ Butir Soal } \\
\cline { 2 - 3 } & Kurang & \multicolumn{2}{c}{2} \\
\hline Penalaran proporsional & Cukup & Cukup \\
\hline Pengontrol variabel & Baik & Kurang \\
\hline Penalaran korelasi & Kurang & Kaik \\
\hline Penalaran probalistic & Kurang & kurang \\
\hline Penalaran hipotesis-deduktif & Baik & Cukup \\
\hline Penalaran konservasi & &
\end{tabular}

Tabel 4 memperlihatkan bahwa siswa dengan gaya belajar auditorial untuk setiap indikator soal memiliki rentang nilai yang bervariasi, mulai dari baik, cukup, dan kurang. Berbeda dengan siswa yang memiliki gaya belajar visual dan kinestetik, siswa dengan gaya belajar auditorial sebagian besar menunjukkan nilai kurang pada setiap indikator penalaran ilmiah. Siswa dengan tipe gaya belajar ini kurang memiliki kemampuan dalam indikator penalaran proporsional, pengontrolan variabel, penalaran 
probabilistik, dan penalaran hipotetis-deduktif. Artinya siswa dengan tipe gaya belajar kinestetik belum memiliki kemampuan untuk membandingkan dua varibel suatu fenomena berdasarkan rasio konstan, mengontrol suatu variabel, menggunakan informasi untuk membuat suatu kesimpulan yang mungkin terjadi berdasarkan perhitungan peluang, dan membuat hipotesis dari sebuah teori dalam memecahkan suatu masalah. Pada indikator penalaran korelasi dan penalaran konservasi memiliki rentang nilai baik, artinya siswa dengan gaya belajar auditorial memiliki kemampuan yang baik dalam mengidentifikasi hubungan timbal balik antar variabel serta memiliki pemahaman bahwa sifat-sifat tertentu pada suatu benda tidak berubah.

Berdasarkan hasil penelitian yang telah dilakukan menujukkan bahwa gaya belajar yang banyak digunakan oleh siswa smp adalah gaya belajar visual. Hal ini berdasarkan skor nilai pada setiap indikator soal penalaran ilmiah untuk siswa dengan gaya belajar visual bernilai baik. Siswa dengan gaya belajar visual memiliki kemampuan menghafal dan memahami suatu informasi dengan cara memvisualisasikan gambar dalam pikirannya sehingga siswa dengan gaya belajar visual ini memiliki kemampuan penalaran ilmiah yang lebih baik dibandingkan siswa dengan gaya belajar kinestetik maupun auditorial.

\section{SIMPULAN}

Hasil penelitian menunjukkan bahwa gaya belajar yang banyak digunakan oleh siswa smp adalah gaya belajar visual. Siswa dengan gaya belajar visual ini memiliki kemampuan penalaran ilmiah yang lebih baik dibandingkan siswa dengan gaya belajar kinestetik maupun auditorial. Selain itu, secara keseluruhan siswa smp belum memiliki kemampuan untuk membandingkan dua varibel suatu fenomena berdasarkan rasio konstan yang artinya siswa smp memiliki kemampuan penalaran ilmiah pada indikator hipotesis-deduktif yang rendah.

\section{UCAPAN TERIMAKASIH}

Ucapan terimakasih saya sampaikan kepada para dosen pembimbing, guru-guru SMPN 15 Kota Sukabumi, suami, orangtua, dan teman-teman seperjuangan yang telah banyak membantu dan berkontribusi dalam peyusunan jurnal ini.

\section{RUJUKAN}

Bachtiar, R. W. (2013). PENGEMBANGAN INSTRUMEN PENGUKURAN KEMAMPUAN PENALARAN ILMIAH FISIKA (KAJIAN KEMAMPUAN PENALARAN ILMIAH MAHASISWA PENDIDIKAN FISIKA). 37, 1-7.

Bo, Y. (2019). Evaluation of the Scientific Reasoning Skills of 7th Grade Students in Science Course. 7(6), 1430-1441. https://doi.org/10.13189/ujer.2019.070610

Chania, Y., Haviz, M., \& Sasmita, D. (2016). Hubungan Gaya Belajar Dengan Hasil Belajar Siswa Pada Pembelajaran Biologi Kelas X SMAN 2 Sungai Tarab Kabupaten Tanah Datar. 8(1), 77-84.

Daik, A. K. V, Abi, A. M., \& Bien, Y. I. (2020). Analisis gaya belajar matematika pada siswa kelas vii smp negeri oebaki. 2(1), 18-24.

Haryono, A. T. (2018). Profil Kemampuan Penalaran Induktif Matematika Mahasiswa Pendidikan Matematika UNIPA Ditinjau Dari Gaya Belajar. 1(2), 127-138.

Mufidah, L.-L. N. (2017). Memahami Gaya Belajar untuk meningkatkan Potensi Anak. In Martabat: Jurnal 
Perempuan dan Anak (Vol. 1, Issue 2). https://doi.org/10.21274/martabat.2017.1.2.245-260

Ramdhan, B., Susilawati, L., \& Ratnasari, J. (2012). Pengaruh Model Pembelajaran Contextual Taeching andLearning (CTL) Terhadap Keterampilan Proses Sains Siswa SMAN 1Cisaat. Jurnal IImiah Pendidikan Biologi Dan Sains.

Sutarno, S., \& Bengkulu, U. (2017). Profil Penalaran IImiah ( Scientific Reasoning ) Mahasiswa Program Studi Pendidikan Fisika Universitas Bengkulu Tahun Akademik Seminar Nasional dan Rapat Tahunan Bidang MIPA 2014 | SEMIRATA. May 2014.

Yuliati, L., Mufti, N., Fisika, P., \& Malang, P. N. (2016). PENYELESAIAN MASALAH SINTESIS FISIKA. 1, 1594-1597.

Zhou, S., Han, J., Koenig, K., Raplinger, A., Pi, Y., Li, D., Xiao, H., Fu, Z., \& Bao, L. (2016). Assessment of scientific reasoning: The effects of task context, data, and design on student reasoning in control of variables. Thinking Skills and Creativity, 19, 175-187. https://doi.org/10.1016/j.tsc.2015.11.004 